\title{
Into the decolonial encruzilhada: the Afrofuturistic collages of Luiz Gustavo Nostalgia as the artistic materialization of cruzo.
}

\author{
Keywords \\ Afrofuturism, Design, Encruzilhada.
}

The task of reviewing the silences present in hegemonic histories emerges at the beginning of the 20th century, seeking to provide a more amplified way of understanding the history of peoples and nations subjected to colonial subjugation. Rufino (2019) considers that this space of decolonization presents itself under the name of "encruzilhada" (crossroads) and understands the potentialities of the orixá Exu, of Yoruba spirituality: the orixá of communication, of the paths and the guardian of axé (vital energy). Exu disarray what exist to reconstruct- therefore, since the encruzilhada is Exu's place, it is a space that allows the crossing of knowledge produced as deviations from colonial impositions on socalled official knowledge, a process which the author names "cruzo" (cross): the encruzilhada is a refusal to everything put as absolute; Exu is the movement of that encruzilhada. In addition to the positivization of the knowledge and ways of living of peoples who have suffered, over the centuries, from numerous processes of inferiority, it is necessary to insert this knowledge in the cultural elements of the present- and in the conceptions about the future. It is in this context that, regarding the experience of Afrodiasporic peoples, a global aesthetic movement that encompasses arts, literature, audiovisual and academic research emerges: Afrofuturism (YASZEK, 2013). Afrofuturism goal is to connect the dilemmas of the African diaspora to technological innovations, commonly unavailable to the descendants of the enslaved, and it aims to establish possible future scenarios - scenarios that contemplate the presence and, furthermore, the protagonism of black people (YASZEK, 2013). To this end, the movement breaks with the Western linear chronology and starts to consider time in a cyclic way, interweaving past, present and future in a single composition: in the same way that Exu, in the Yoruba cosmology, killed a bird yesterday with a stone that has only been thrown today, Afrofuturism weaves a web of historical and cultural retaking of African memory with questions that arise from the reflection of the problems faced by black people in the present, in order to think about a positive and possible future, once a dystopian scenario is already weighing on the shoulders of them. In the frontier of visual arts and design, Luiz Gustavo Nostalgia, a creator based on Rio de Janeiro, dismantles existing images and rearranges them through collages to create a new intention of meaning. His work evokes the cruzo on the principle of rearranging - central to collageswith the widespread rearrangement of our ways of living and understanding society - based on an Afrofuturistic conception of world - by celebrating African motifs, culture and spirituality, allied to the already acquainted aesthetics of "future" (such as the galaxy, bright lights and robotic elements). Through your creation, the artist is capable of presenting a future where black people do exist as protagonists and have their culture, past and roots celebrated. 